\title{
THE IMPACT OF FEMALE ATTRACTIVENESS IN SPY
}

\author{
Veronika Juliani Pangjaya, Priska Febrinia Handojo \\ English Department, Faculty of Letters, Petra Christian University, Surabaya, East Java, Indonesia \\ e-mail:vropangjaya@gmail.com ; priskafebrinia@peter.petra.ac.id
}

\begin{abstract}
This thesis discusses the impact of female attractiveness on the female character which is related to the way Spy sees attractive women and what the impacts to them are. There are criteria for female attractiveness that are displayed by the film such as physical attributes and traits. In order to show the criteria of attractive women and the responses that they get, I use stereotyping theory. Women who are physically attractive get better treatment, but in order to get that, they have to dress with a certain style that men favor. For the women who are considered as unattractive, they will be ignored by men. In conclusion, I find out that the appearance and the attitude of the female character still depend on men's view. Women can also be seen as attractive from their characteristics. Attractiveness also has huge influences on the way women get treated by men.
\end{abstract}

Keywords: Stereotype, attractiveness, female attractiveness

\section{INTRODUCTION}

Comedy is the most entertaining genre in film industry and the main emphasis of this genre is humor. Comedy genre is defined as "the genre of a film that uses humor as driving force" ("tsl", n.d.). In 2015, Hollywood presents action-comedy films that success to lift up a woman as the main character which is Spy. Spy is action comedy film, released on June 5, 2015, written and directed by Paul Feig. Feig managed to elevate the role of large-bodied female in the film industry, which broke Hollywood custom, where usually handsome actor and sexy actresses becomes the domain in films (Bartyzel, 2015).

The Hollywood film entitled Spy portrays the life of Susan Cooper, a desk-bound CIA employee. Susan has a close friend in the agency which is Nancy. Nancy is also a desk agent like Susan. Nancy and Susan are not as popular as Karen. Karen is a good looking female spy who is very excellent in her job. When Fine was assumed to have been killed by Raina, Crocker as the director was desperate because Raina knows all of her agents name from Karen who betrays the agency. In the end, Susan finds out that Fine is not dead yet and he killed Karen because she is the one who sells all agent's name to Rayna, the villain. Rayna is a female villain who runs her father business as a nuclear bomb seller.

This film is dominated by female character and all of them have different appearance and characteristic. Their appearance and characteristic could be the reasons why each of them gets a different treatment from the male characters; they also have a different ending. Therefore, I am interested in knowing what is the impact of female attractiveness in this film is.

In this paper, I am interested in knowing the way Spy shows female attractiveness and its impact on female character. The way Spy displays female attractiveness will show that there are criteria for female attractiveness. The impact of this attractiveness will show that there are reward and punishment for female attractiveness.

I will use the stereotyping theory, especially gender stereotypes, physical attractiveness stereotype, and "beautiful-is-good" stereotype to analyze the way the film shows female attractiveness and non-attractiveness and the impact of female attractiveness. A gender stereotype "consists of beliefs about the psychological traits and characteristics of, as well as the activities appropriate to, men or women" (Begley, 2000, p. 66). Gender stereotype shapes society's view toward women and men and set up social categories for gender. The content of gender stereotypes can be separate into four components that people use to differentiate male from female-traits, behaviors, physical characteristics, and occupations (Deaux \& Lewis, 1984, p.46).

The physical attractiveness stereotype describes "that attractiveness of an individual can distort others perception of that individual's character qualities" (Coutts, Gruman, Schneider, 2005, 
p. 357). Attractive people are portrayed as someone that preferable rather than the unattractive ones. People tend to think that attractive people are having more skills and more competence in doing things or "beautiful-is-good" stereotype (Berscheid, Dion, Walster, 1972, p.175). Attractive people maintain their appearance to keep their good looking and impression. They are perceived to have a myriad of desirable personality (self-esteem, self-concept, and emotional stability) and social characteristics (Prestia, Silverston, Wood, Zigarmi, 2002, p.5).

\section{THE IMPACT OF FEMALE ATTRACTIVENESS}

This chapter will analyze the way the film constructs female attractiveness and nonattractiveness and the impact of it. As a film with predominantly female on its leading and supporting characters, Spy reveals several factors that can shape the viewer's perspective about attractiveness. Susan, Nancy, Karen, and Rayna will be the main focus on my analysis. This chapter will be divided into two subchapters. In the first subchapter, I will discuss the way female's physical attributes define what is attractive and what is not and the impact of it. In the second subchapter, I will discuss the characteristics of female characters that show attractiveness and non-attractiveness and the impact of it.

\section{Physical Attributes}

There are four characters that get different treatment and responses about their look; they are Susan, Nancy, Karen, and Rayna. Physically, among all these women, Susan is the fattest of them all. Almost in every scenes Susan wears grey cardigans which is shown that she is not really confident with her body and that is why she uses the color that does not really pop up so everyone does not notice her presence. Her hair styles and color do not really follow the fashion trend. Another character that is not too different from Susan is Nancy. Nancy's appearance is more or less the same as Susan's. Different from Susan and Nancy, Karen has a slender body and beautiful hair. Even though Karen does not appear much in the film, it is trying to show that Karen is the attractive one. The way the film portrays her attractiveness is through her face, hair, and body. She has a fresh and young look seen from her hair and appearance. Karen's hair is stylish and neat. It shows that she styles her hair to make it look like that. Karen is also confident in wearing a dress that shows her cleavage and curve and also fits her body perfectly.

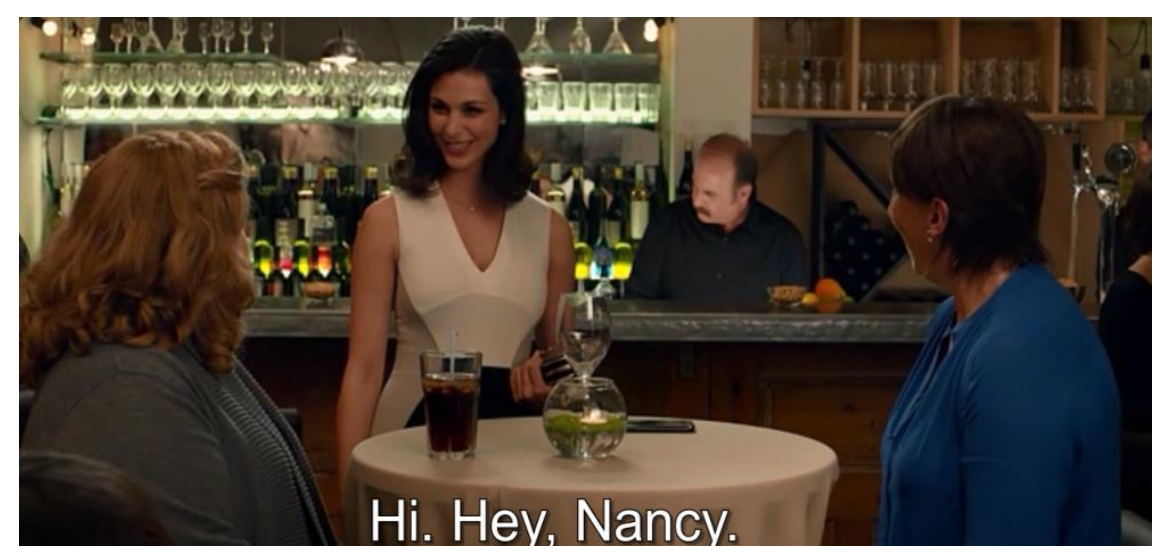

Figure 1: The different way of dresses

Susan and Nancy are displayed differently from Karen even though they work at the same office. Susan and Nancy have less attractive appearance and they do not have enough confidence to wear sexy clothes while Karen is the opposite. Karen is also seen as more sophisticated in wearing cosmetic rather than Susan and Nancy. The film shows that a person who is good at taking care of their look and appearance is more preferable rather than the one that is not. The film also shows what attractive is through the responses that they get. Karen gets a better treatment and responses while Susan and Nancy are not. 
The first different response those women receive is female that is considered attractive by the film is more popular. Karen who is considered as attractive gets a warm welcome from male agents when she enters the room. Compared to Karen, Susan and Nancy are not popular. They only have each other as a friend. Karen also has a good social skill. It can be proven when she talks with the male agents. She has a good conversation with them which mean that she knows how to build a conversation not only with female but also with male. The second different response that they get is the attractive female gets a better service. Karen gets faster service from the bartender, Alan. She has the traits that people like such as pretty face and friendliness to people. These traits make her gets a special treatment from male. Her attractiveness can be a power to influence how male treats her.

$\begin{array}{ll}\text { KAREN } & : \text { Can I have an Old Fashioned, please? } \\ \text { NANCY } & : \text { The service is really slow. } \\ \text { SUSAN } & : \text { Super slow } \\ \text { NANCY } & : \text { Good luck getting that in the next hour. } \\ \text { ALAN } & : \text { Here you go, Miss Walker. } \\ \text { KAREN } & : \text { Thank you. }\end{array}$

The time Susan and Nancy warn her that she has to wait long enough for her drink like them, Karen smiles because she knows that her drink will come right after she orders. Susan and Nancy experience a different treatment. They sure that Karen will also get slow service like them if seen from the way they emphasize about how long they have to wait. The different treatment that they get is because Karen has the appearance that can make people unconsciously treat her better. Karen explains that she and Alan know each other and that is the reason she can get faster service.

The bad treatment that Susan gets because of her appearance is not only from Alan, but also from Patrick, the tech-guy that gives her special equipment. Her spy equipment should cover its true function so that her enemies will not know what that is for. Here Patrick shows his feeling toward Susan through the equipment. He prepares Susan's equipment with a really weird cover. Even Susan and Nancy wonder what Susan has done to him until he gives her bad cover for her equipment.
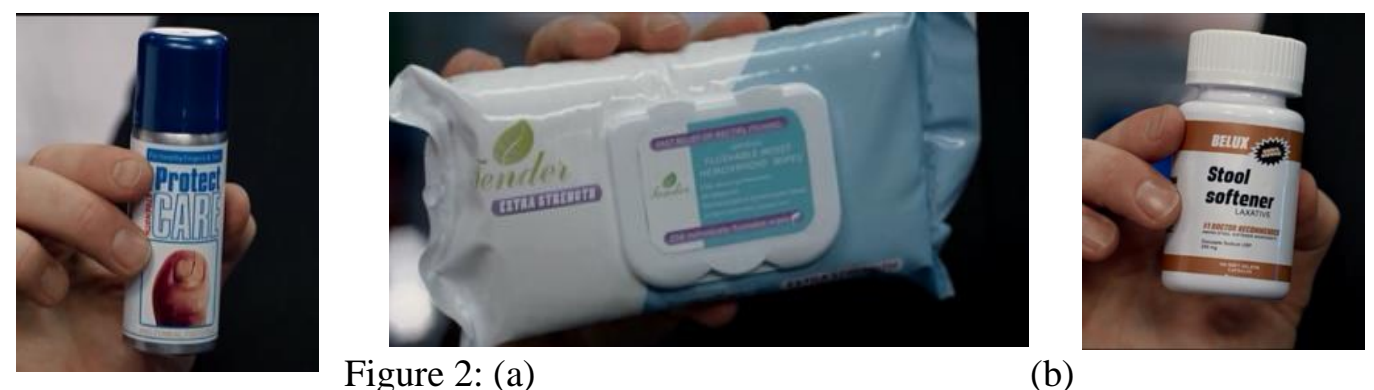

Figure 2: (a)

(b)

(c)

Her second undercover is a divorce house wife who collects porcelain dolls. She also has ten cats and a vice President of the Ames Garden Club. In her second undercover Susan states her dislike of the character. Becomes a divorce house wife means that she cannot maintain a good relationship with her husband and in her identity picture she wears a clothes that saying that she needs a touch of a man.

This film displays that more attractive women can judge less attractive women. Although Susan's appearance is better when she meets Rayna, she still gets mocked by Rayna about her black dress. Rayna is a rich and stylish woman. She mostly uses a tight skirt and a blouse with low cleavage. After Susan helps her from being poisoned, she wants to thank Susan, but she also mentioned about Susan's dress.

RAYNA

: I would like to take you to dinner to say thank you.

And we must discuss this hideous dress. It's just hysterical.

SUSAN

: Oh, good, that's what I was hoping for. 


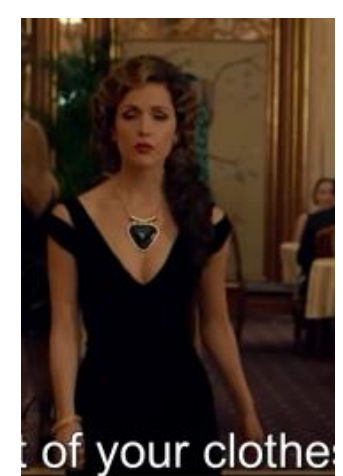

Figure 5:

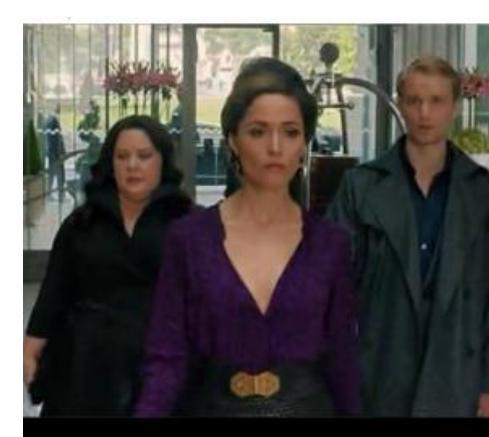

(b)

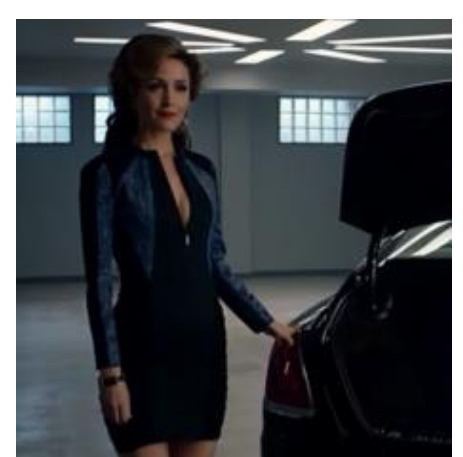

(c)

Rayna who has better style and more attractive appearance judge Susan's look, she said that Susan's look is hideous. It means that she knows the better style. This scene shows how male consider attractiveness is different from how female considered attractiveness.

Karen and Rayna who has slender body and better appearance is what man prefers. What is considered attractive by the film is female who wears tight short skirt, tight trouser, high heels, clothes with low cleavage, and a nice hairstyle. Not only that, female is also considered attractive when they wears make up and buy an expensive clothes. A female who is divorce, has lots of kid, and cannot fit the society are considered unattractive. People unconsciously give better treatment to attractive individual rather than the unattractive one.

\section{Character Traits}

The film displays female attractiveness not only from the physical appearance but also from the characteristic traits of each character. Characteristic is one of the aspects that can be a bench mark of attractiveness.

Attractive person is having self-esteem about themselves. Rayna, in this case, is having a good confident in a way she sees herself toward Fine. She believes that Fine wants to be with her although Fine actually just pretending to like her. Compared to Rayna, Susan does not have the confident about her feeling toward Fine. However, the film also displays Rayna as an unattractive female through the way she reacts to a particular situation. On one hand the film displays Rayna as an attractive female and has a good confident about herself. On the other hand the film also displays her as a dominant female who cannot control her emotion and heartless to her employee.. Rayna is always displayed as a character that bossy and does not care about her employee and what happened to them andin one scene the film shows that she cannot handle herself and her anger explodes to Susan and Nancy. Moreover, Susan is also portrayed as an attractive female because of her loyalty. Susan is depicted as someone who is loyal to her agency. Even though at first not many people trust her to be a field agent, in the end she gets what she deserves. Compared to Susan, Karen is depicted as a female that not loyal to her agency. Karen who is working in the same company with Susan chooses to betray her agency and become double agents. She sold the entire name of the field agents to Rayna. Karen, who has a disloyal character, gets a punishment. Even though at first Karen is displayed as an attractive female and liked by many people especially male, she gets killed also by male that wants to protect Susan.

\section{CONCLUSION}

First, in the terms of how attractiveness seen from female physical traits, I found out that female can be treated differently based on their appearance. The different treatments and responses that they get is not only caused by their body shape but also caused by their look. Indeed, female with slender body will be more likely to be treated better than the one who does not. From the analysis, I can conclude that female who has better appearance and slender body is preferable rather than the one who has big body.

Furthermore, the film displays a better appearance is when the female consuming cosmetics, expensive and tight clothes, and also high heels. I conclude that the film is giving the audience a 
stereotype, that to be attractive, that in order to perceived as attractive, a female has to conform to a certain way of dressing-up and also must have a slender body.

Second, in analyzing the characteristic traits of the female character, I found out that a female can be considered attractive not only by their physical look appearance, but also by their characteristic. A Female with good characteristic is preferable rather than the unattractive one. The film shows this through the way each of them gets the compliment and punishment of their character. There are several factors of characteristic that can be a bench mark of attractiveness. The first factor is the way female character control their emotion. Susan is displayed as a female who is able to control her emotion. She is calm while Rayna is not. Susan does not easily lose control of her emotion even though she is under pressure. Different to Susan, Rayna cannot control her emotion when she is under pressure. The concept believed here is that the attractive females have calmness and Rayna does not have it. The film shows that a dominant female who is bossy and assertive is not attractive.

The second factor is female who has confidence is attractive. The film displays Rayna as a female that has confidence in terms of love. She thinks that Fine wants to be with her is because of her appearance where actually Fine wants to be with her is only to catch the villain. She does not realize about this because she knows she is physically attractive. The way she sees herself is full of confidence not like Susan who does not have confidence about herself toward Fine. Susan is never brave enough to state her feelings toward Fine. She chooses to stay quiet about her feeling and do anything that Fine and hope that one day Fine will likes her too. Susan's view about herself is lack of confidence; she does not believe that she is attractive enough to be liked by Fine.

The third factor is loyalty, where loyal female is more preferable rather than the one who is not. Susan gets her rewards which are compliments from the male agents and Crocker and also promotion to become a full field agent. Not only that, a female who is loyal especially to a male will get her reward. The reward here is getting protection by a man, especially a man that is special to her. While the one who is not loyal gets her punishment by getting killed. Hence, I can conclude that to be considered attractive female supposed to be able to control their emotions, have confidence, and be loyal.

Having analysed the female attractiveness by using physical attractiveness stereotype and beautiful-is-good stereotype above, I found that all female in the Spy film can be considered as attractive based on different aspect. These findings answered my thesis statement on how the film shows female attractiveness and non-attractiveness and what is the impact of it. I also find out that most female attractiveness depends on how the male characters react, which lead me to the conclusion that this film is not really a feminist film, because of the appearance and the attitude of the female character is still depends on man's view.

Through this research we can learn how attractiveness is shown by the film. The conversations and scenes in the film lead us to know what is attractive and not. The media often displays a figure of ideal beauty or something that female or male can considered as attractive. Hopefully, people will be more careful and aware that media is trying to shape their view even though through something simple as a film. Also, hopefully female can be wiser in terms of choosing their clothes and looking good so they do not just blindly follow what male want them to be.

\section{REFERENCES}

Bartyzel, M. (2015, june 9). Forbes. Retrieved September 30, 2015, from Forbes.com: Paul Feig and Melissa McCarthy are building an empire on a premise that goes against the very foundation of Hollywood habit.

Begley, S. ( 2000, November 6). The Stereotype Traps. Newsweek, Vol. 136 Issue 19, 66-67.

Deaux, K., and Lewis, L.L. (1984). Structure of gender stereotypes: Interrelationships among component and gender label. Journal of Personality and Social Psychology, 46.

Coutts, L. M., Gruman, J. A., Schneider, F. W. (2005). Applied social psychology: Understanding and Addressing Social and Practical Problems. SAGE Publications. Kindle Edition, 357.

Berscheid, E., K. K. Dion, E. Walster, and G. W. Walster. (1971) "Physical attractiveness and dating choice: A test of the matching hypothesis." Journal of Experimental Social.Psychology 7: 175 . 
Prestia, S., Silverston, J., Wood, K., Zigarmi, L. (2002). The Effects of Attractiveness on

Popularity; an Observational Study of Social Interaction Among College Students. Perspective in Pyschology, 5.

Tsl. (n.d.). Comedy. Retrieved from http://thescriptlab.com/screenplay/genre/comedy 